\title{
Selected geotourist attractions of Death Valley, USA
}

Wybrane atrakcje geoturystyczne Doliny Śmierci, USA

\section{Ewa Krzeszowska}

Instytut Geologii Stosowanej, Politechnika Śląska, 44-100 Gliwice, ul Akademicka 2, e-mail: ewa.krzeszowska@polsl.pl
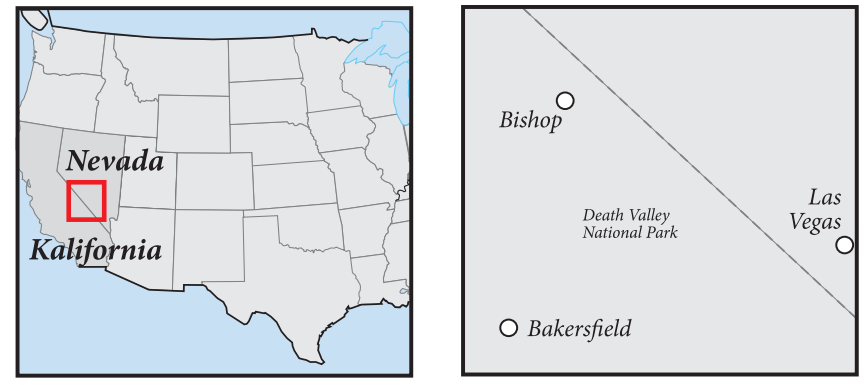

Abstract: Death Valley National Park located in the U.S. states of California and Nevada is one of many units within the National Park Service established because of their exceptional natural and geological values. Death Valley National Park is renowned worldwide for its perfectly exposed, complex, unique and diverse geological resources. Within the park visitors encounter representatives of many geological epochs, from Precambrian metamorphic rocks exposed in the Black Mountains to recent desert sediments. This paper presents the geology of Death Valley and some of the most interesting geosites: Zabriskie Point, Badwater Basin, Devil's Golf Course, Harmony Borax Works and Ubehebe Craters. Key words: Death Valley National Park, Basin and Range Province, geotourist attractions, geology

Treść: Park Narodowy Doliny Śmierci położony w stanach Kalifornia i Nevada jest jednym z wielu parków narodowych Stanów Zjednoczonych utworzonych ze względu na szczególne walory przyrodnicze i geologiczne obszarów. Ze względu na ogromna różnorodność geologiczna park ten jest obiektem światowej klasy. Na obszarze Doliny Śmierci odsłaniaja się skały wielu okresów geologicznych, od prekambryjskich skat metamorficznych (Black Mountains) po wspótcześnie tworzace się osady pustynne. W artykule przedstawiono budowe geologiczna Doliny Smierci oraz kilka najciekawszych obiektów geoturstycznych: Zabriskie Point, Badwater Basin, Devil's Golf Course, Harmony Borax Works, Ubehebe craters.

Slowa kluczowe: Park Narodowy Doliny Śmierci, Prowincja Dolin i Grzbietów, atrakcje geoturystyczne, geologia

\section{Introduction}

In the USA, there exist 58 national parks, most of which are located in the western part of the country where they cover vast wilderness areas. The American national parks are established by the Congress legislation, come under the federal law and are administered by the federal National Park Service (NPS). In the parks the NPS Rangers, wearing characteristic, green uniforms and hats, are not only responsible for law enforcement but are also the trip organizers and qualified guides, and interpreters. In each park one private company is granted a concession for providing the high-quality visitor services (hotels, campgrounds, restaurants, gift shops, etc.). Concessioners also care for the park infrastructure.

The Death Valley belongs to the most interesting national parks of high geodiversity.

\section{Localization and accessibility}

Death Valley is located in the Western United States, mostly in the California State (Inyo County) and, partly, in Nevada (Nye County). The valley is bordered by the Panamint Range with the Telescope Peak (3,368 meters a.s.l.) as the tallest mountain and somewhat lower Amargosa Range (Fig. 1).

Since 1933 the valley has been the national monument until October 31st, 1994 when it was designated the Death Valley National Park. The area under park jurisdiction covers 8,374 square kilometers (length - 225 kilometers, width from 8 to 25 kilometers). This is the hottest and the driest land in North America, and the lowest elevation in the park (86 meters below sea level) is the lowest point in both the North and South Americas.

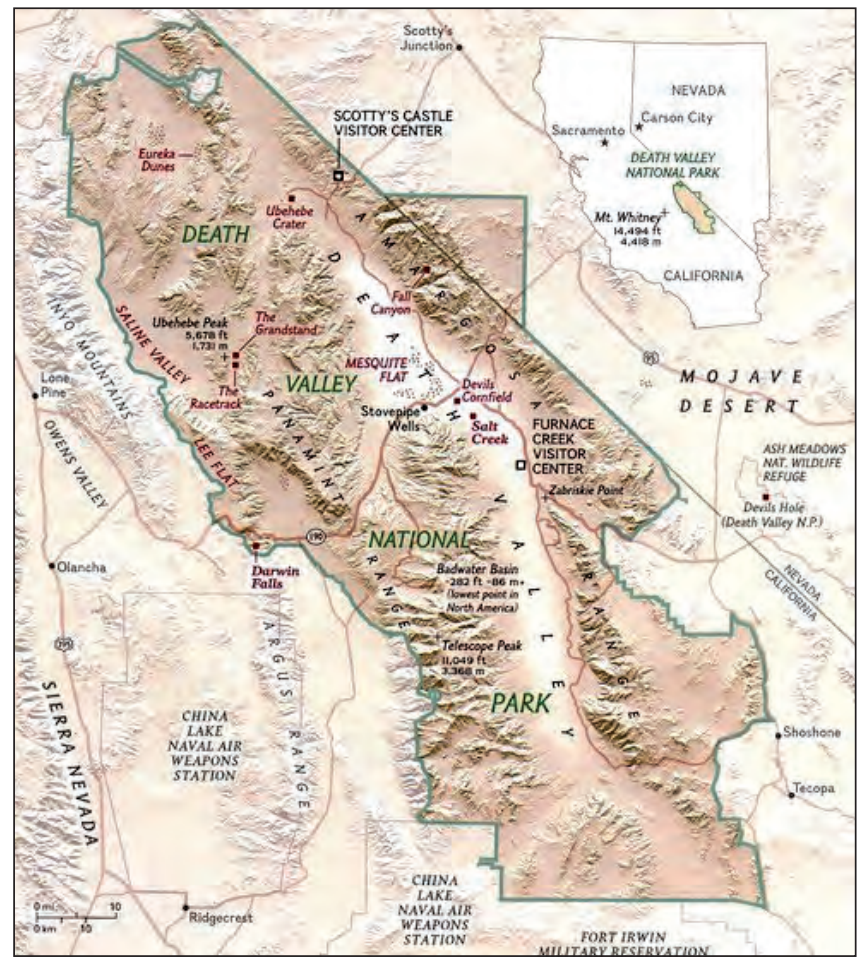

Fig. 1. Map of Death Valley National Park (http://mappery.com/map-of/Death-Valley-National-Park-Map) • Mapa Parku Narodowego Doliny Śmierci (http://mappery.com/map-of/Death-Valley-NationalPark-Map) 
In the past, the valley was a site of mining operations. Among others, gold, silver copper ores as well as borax were intensively extracted at various locations. The name "Death Valley" was given by gold prospectors who sought to cross the valley in 1849 heading to the California goldfields and survived despite the short water stocks.

Death Valley area is accessible only by car. The entrance fee is $20 \$$ per vehicle (despite the number of passengers) and the ticket is valid for 7-days period from the purchase date. Better solution is to buy the Annual Pass, which covers entrance fees at all national parks in the USA for one year (cost: $80 \$$ per vehicle, as for 2011). The pass fee includes also the park map and the current park newsletter.

A visit to the Death Valley National Park should start at the visitor center, where tourists can find exhibition presenting the history, geology and nature of the valley. Also, a short film is available providing a perfect introduction to the area. Due to vast area of the park and a great number of tourist attractions, it is recommended to carefully plan the visit before arrival using e.g., the perfect website of the park. During the tourist season and if weather allows (i.e., at temperatures up to $40^{\circ} \mathrm{C}$ ) it is possible to visit some objects with the park ranger.

\section{Geological setting}

Death Valley is located within the Basin and Range Province, which is a part of the Central Cordillera (Fig. 2) - the Mesozoic orogenic belt (Stanley, 2002). The characteristic feature of the Basin and Range Province is a system of

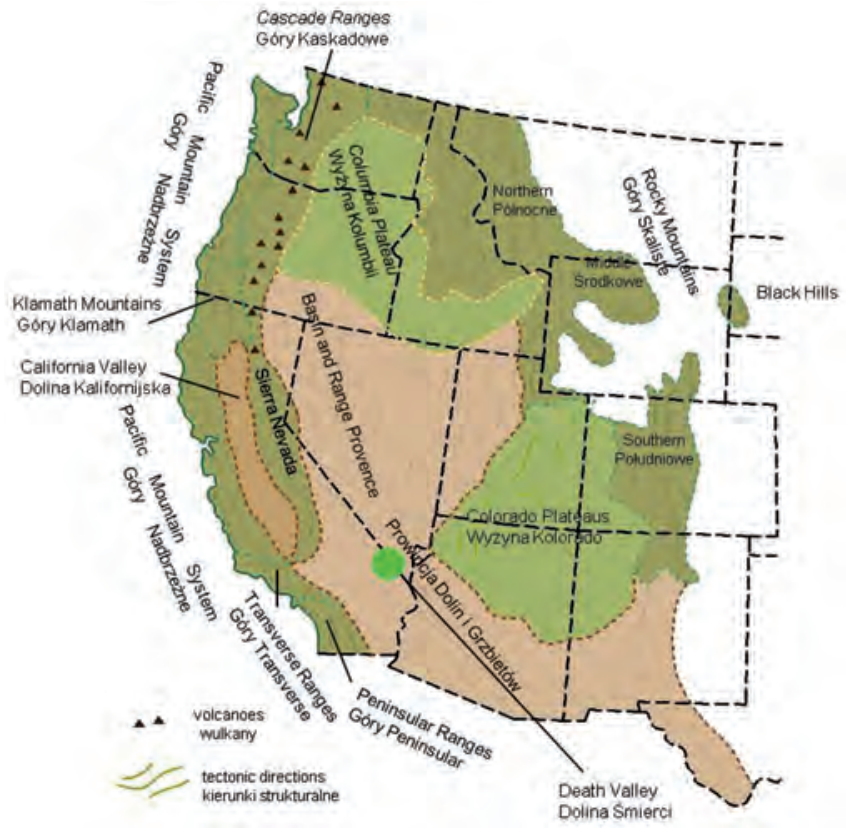

Fig. 2. Location of Death Valley related to the main geological provinces of the western United States (after Stanley, 2002) • Lokalizacja Doliny Śmierci na tle głównych prowincji geologicznych zachodnich Stanów Zjednoczonych (wg Stanley, 2002)

parallel, tectonically controlled valleys and ranges (Fig. 3). The fault systems and the distinct thinning of the lithosphere observed in the Basin and Range Province (to 20-30 kilometers) indicate strong extensional movements.
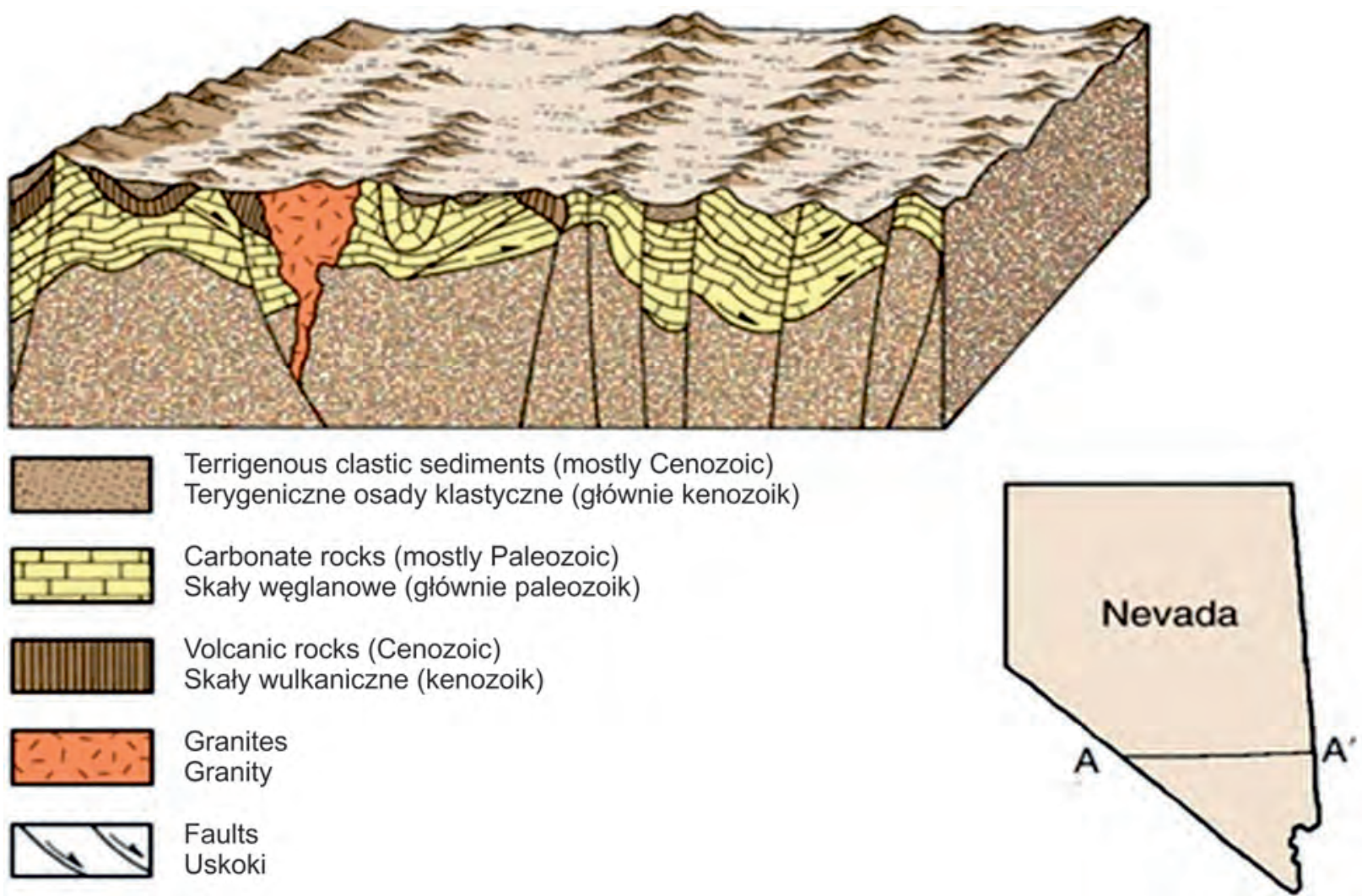

Fig. 3. Simplified geological cross-section through the Basin and Range Province in Nevada (after geomaps.wr.usgs.gov) • Schematyczny przekrój geologiczny przez Prowincję Dolin i Grzbietów na terenie stanu Nevada (wg geomaps.wr.usgs.gov) 

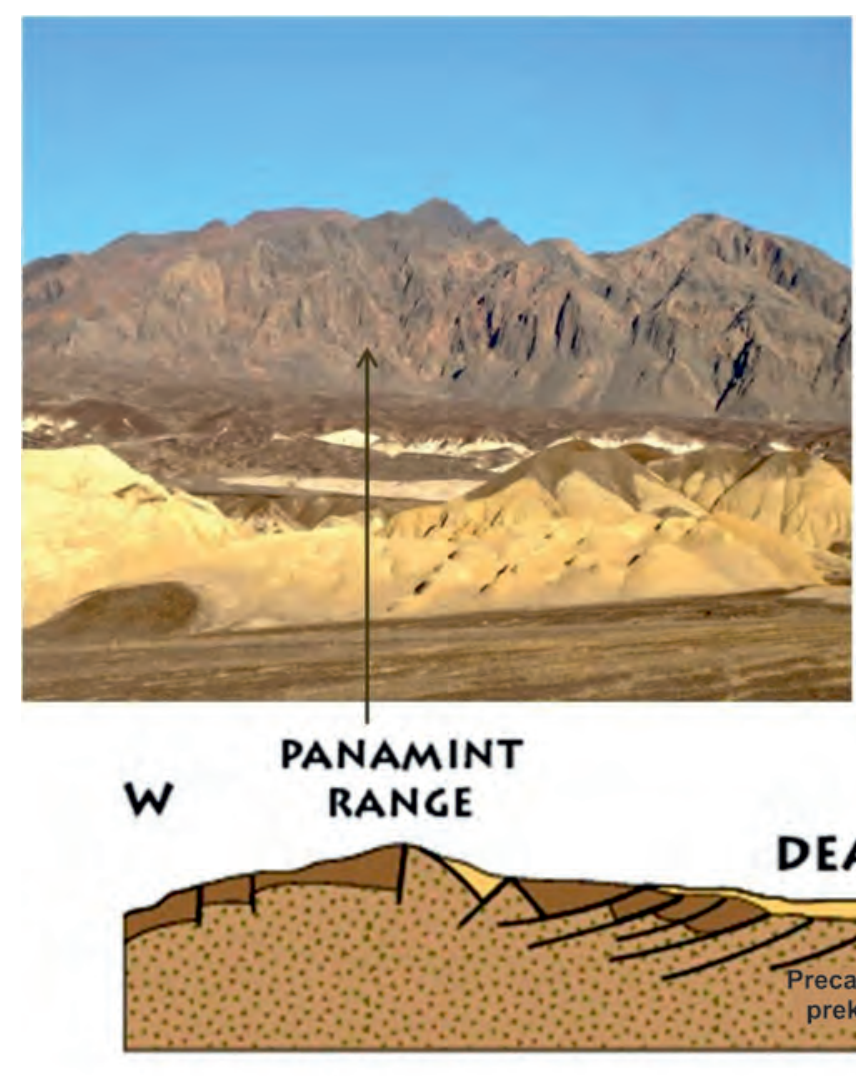

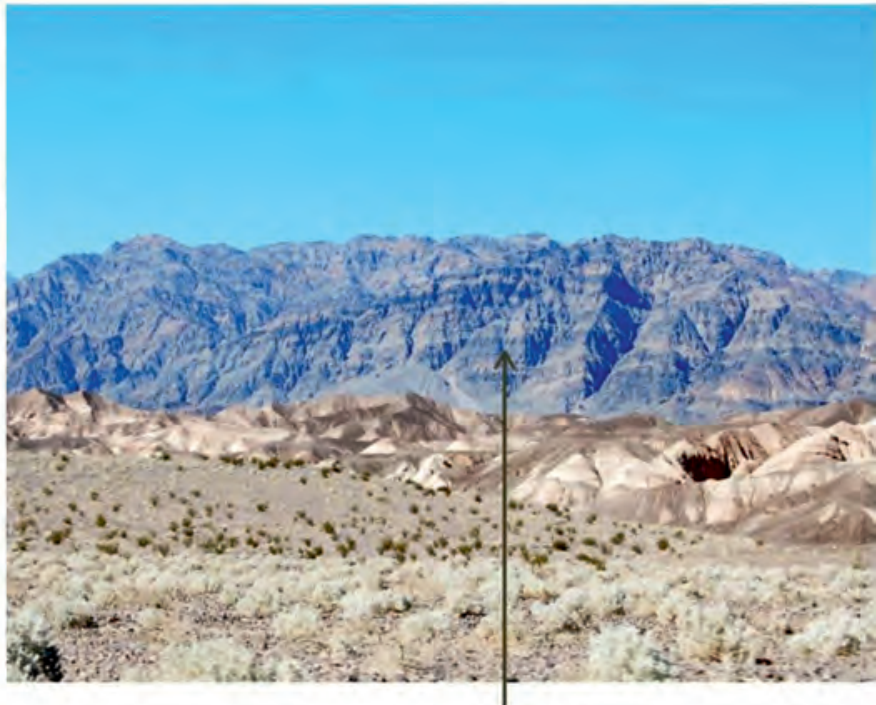

BLACK MOUNTAINS

$\mathbf{E}$

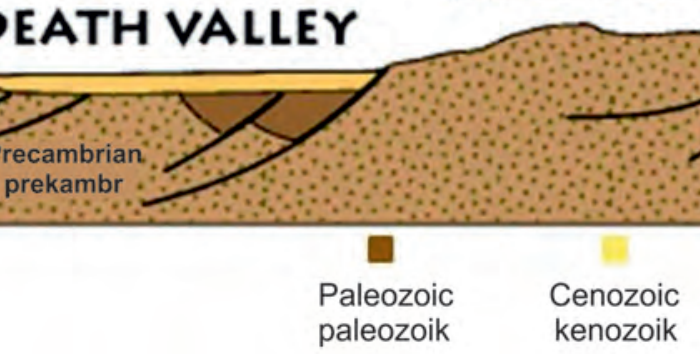

Fig. 4. Geologic cross-section through the southern part of Death Valley (after geomaps.wr.usgs.gov) illustrated by general views of bordering mountain ranges, phot. E. Krzeszowska • Schematyczny przekrój przez południową część Doliny Śmierci (wg geomaps.wr.usgs.gov) ilustrowany ogólnymi widokami otaczających łańcuchów górskich, fot. E. Krzeszowska

The basement of the province is the rejuvenated Central Plate built of Proterozoic rocks belonging to the Hudsonian Province and their Upper Proterozoic-Paleozoic platform cover folded at the end of Mesozoic (Mizerski, 2004). The Mesozoic era was a period of strong tectonic activitity (folding and faulting) in the Basin and Range Province, intermitted by the episodes of stability when erosion of newly formed mountain ranges have dominated. The final setting of the region is related to the Neogene (Miocene) movements of the Alpine orogeny (Levin, 2005).

The geological setting of Death Valley is typical of the pattern observed within the Basin and Range Province. The valley is a tectonic graben, which geological history has started in the Miocene (Fig. 3). It is cut by the Furnace Creek Fault Zone (FCFZ) - a 200-kilometers-long and 30-kilometers-wide structure extending from the Amargosa Valley in the eastern California to the Fish Lake Valley in Nevada (Baucke, Cemen, 2007). The FCFZ has formed in the Late Pleistocene and the youngest faults are only 2,000 years old (resulting from 4-6 separate tectonic events in the Holocene and several older ones) (Brogan et al., 1991). In Late Pleisotocene, the main part of the valley together with the Panamint Range bordering it from the west formed a single tectonic block, which has migrated tectonically along the strike-slip Furnace Creek Fault for about 30 kilometers, as concluded from the studies of conglomerates composed of Paleozoic rocks (Baucke, Cemen, 2007; Konott et al., 2005). Recently, the Furnace Creek Fault runs in the eastern part of the valley, at the foot of the Amargosa Range and its branch - the Black Mountains.

Both the western (Panamint Range) and the southeastern (Amargosa Range) slopes of Death Valley are built of strongly folded and faulted, Paleozoic marine sediments (Tanner, 2002). In the southeastern part of the valley, the Black Mountains are composed of the Amargosa Chaos Formation (Fig. 4, Fig. 5) (Hall, 2007). The valley itself is filled with Miocene-Pliocene Furnace Creek Formation sediments covered by Quaternary strata (Fig. 5) (Tanner, 2002).

\section{Characterization of selected geosites in the valley}

The Zabriskie Point is one of several outstanding overlooks in the valley. It is located close to the Highway 190 the main communication road in the valley - about 5 kilometers south of the Furnace Creek Visitor Center. Usually, this is the first site visited by tourists arriving from Las Vegas. Around the Zabriskie Point there are several trails of various difficulty. 


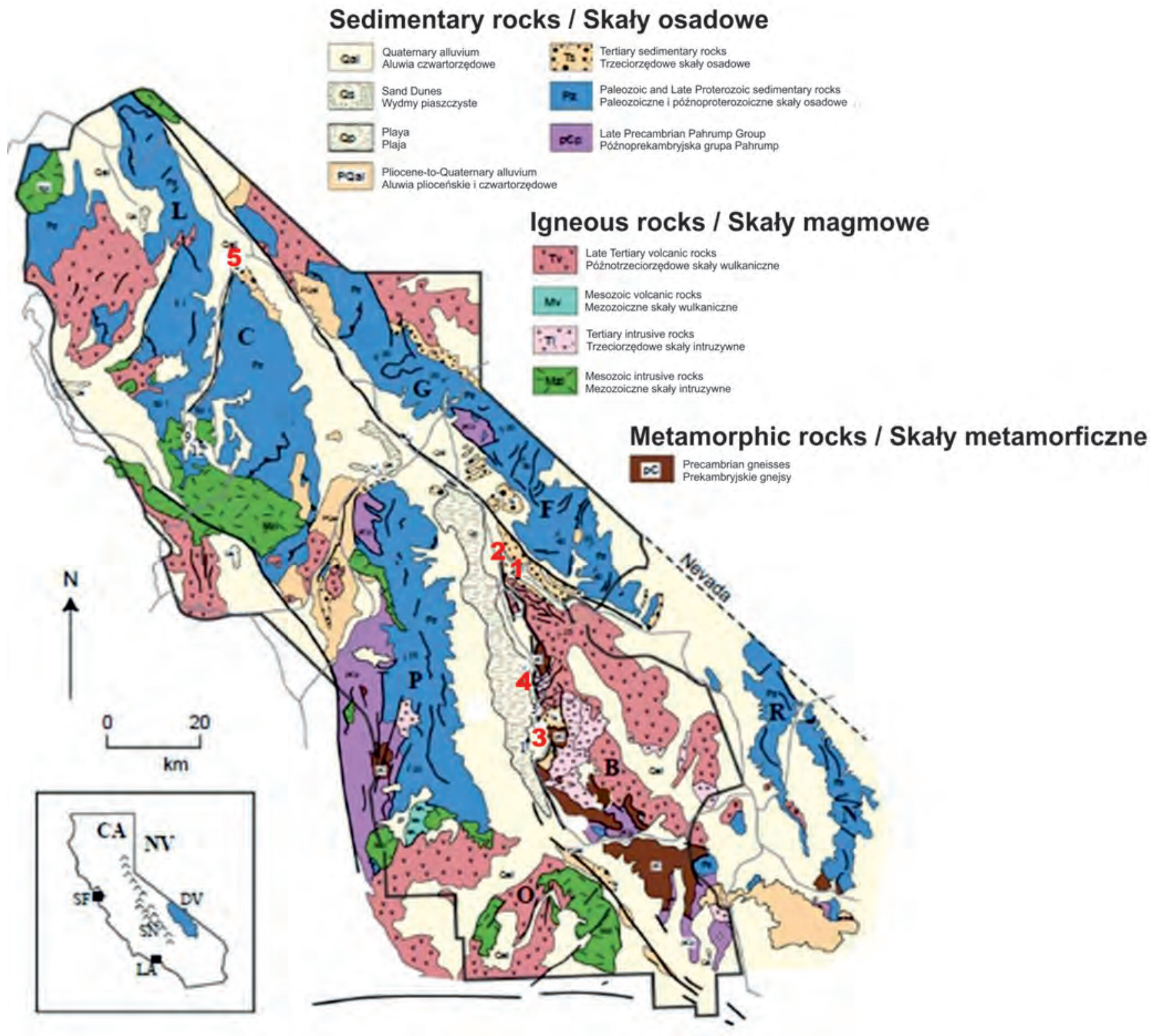

Fig. 5. Geologic map of Death Valley (after Miller, Wright, 2004) • Mapa geologiczna Doliny Śmierci (wg Miller, Wright, 2004)

Explanations / Objaśnienia: B - Black Mountains; C - Cottonwood Mountains; F - Funeral Mountains; G - Grapevine Mountains; L - Last Chance Range; N - Nopah Range; O - Owlshead Mountains; P - Panamint Mountains; R - Resting Spring Range; CA - California; DV - Death Valley National Park; LA - Los Angeles; NV - Nevada; SF - San Francisco; SN - Sierra Nevada Mountains; 1 - Zabriskie Point, 2 - Harmony Borax Works; 3 - Badwater Basin; 4 - Devil’s Golf Course; 5 - Ubehebe Craters

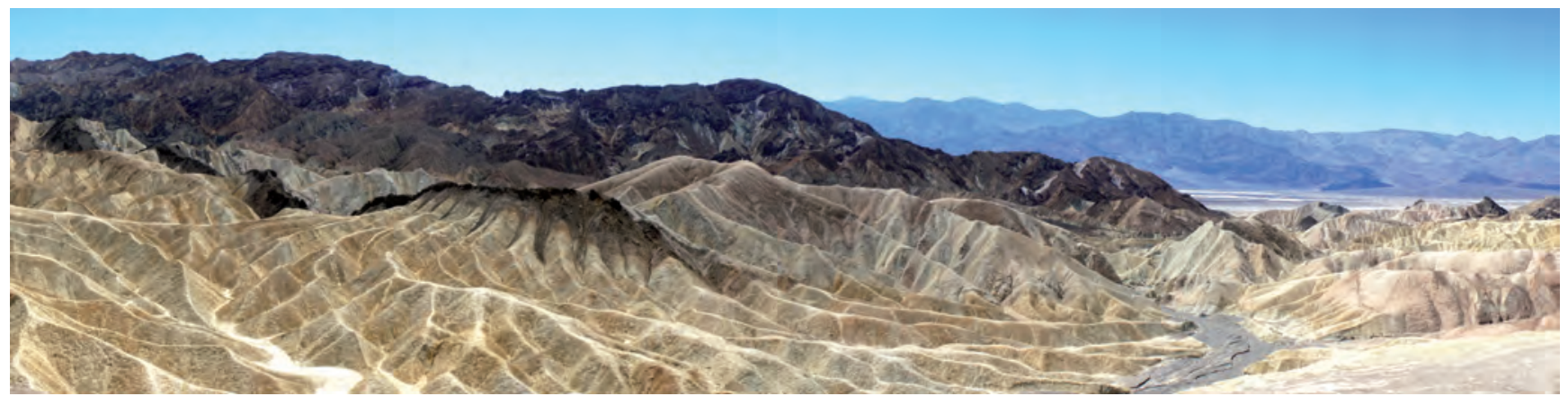

Fig. 6. Miocene-Pliocene Furnace Creek Formation - view from the Zabriskie Point, Death Valley, phot. E. Krzeszowska • Mioceńsko-plioceńska formacja Furnace Creek Formation - widok z Zabriskie Point, Dolina Śmierci, fot. E. Krzeszowska 


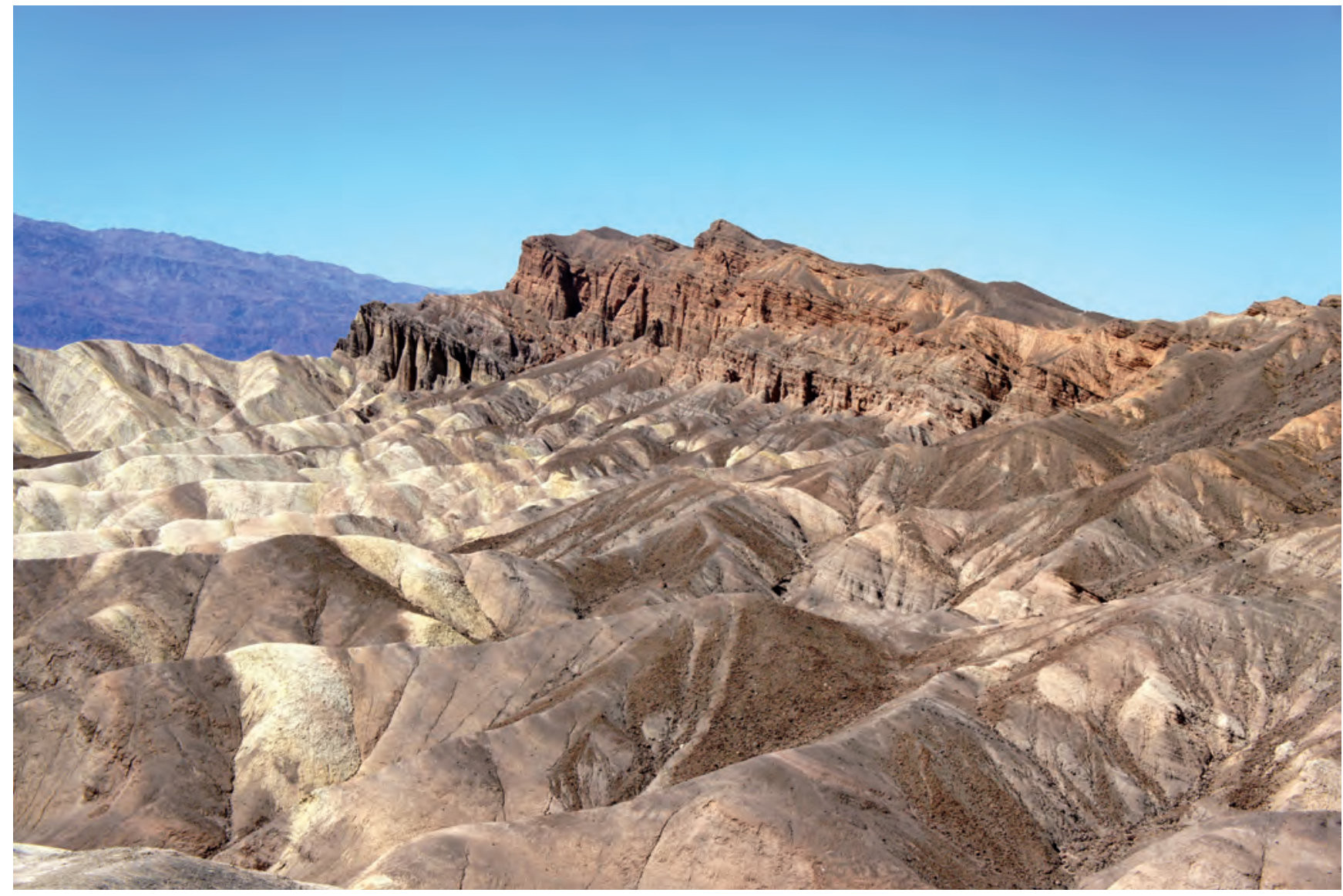

Fig. 7. Laminated lacustrine deposits (mudstones, sandstones), Furnace Creek Formation, Death Valley, phot. E. Krzeszowska • Warstwowane osady jeziorne (mułowce, piaskowce) formacji Furnace Creek, Dolina Śmierci, fot. E Krzeszowska

The rocks around the Zabriskie Point are mostly the Miocene-Pliocene Furnace Creek Formation sediments (Fig. 6, Fig. 7) of total thickness over 2,000 meters (Tanner, 2002). These are chiefly the continental sediments deposited in an inland lake formed about 9 Ma ago. Lithology includes well-sorted, fine-bedded sandstones and mudstones covered locally by dark tuffs originating from Pliocene volcanic eruptions (Tanner, 2002). The recent morphology of this area, named the "Badlands" is an effect of very intensive water erosion. The Furnace Creek Formation includes also the alluvial conglomerates and the fossil alluvial fans. A characteristic feature of the Badlands is the towering rock spire named the Manly Beacon.

In the lower part of the Furnace Creek Formation there are borates accumulations intensively mined in the XIXth century (Kistler, 2005).

The Harmony Borax Works is a site where remnants of past borates mining operations can be visited. The site is located close to the Highway 190, about 1.5 kilometer from the Furnace Creek Visitor Center. A short (0.5 kilometer) but informative educational trail with well-prepared information boards leads the visitors around a few historical objects (Fig. 8). It is worthy to see also the exhibition of the mining industry in Death Valley, which is available at the visitor center.

The borates accumulations in Death Valley are located in the lower part of Miocene-Pliocene Furnace Creek Formation where particular ore zones occupy various stratigraphic positions (Kistler, 2005). Usually, these are layers up to 1 meter

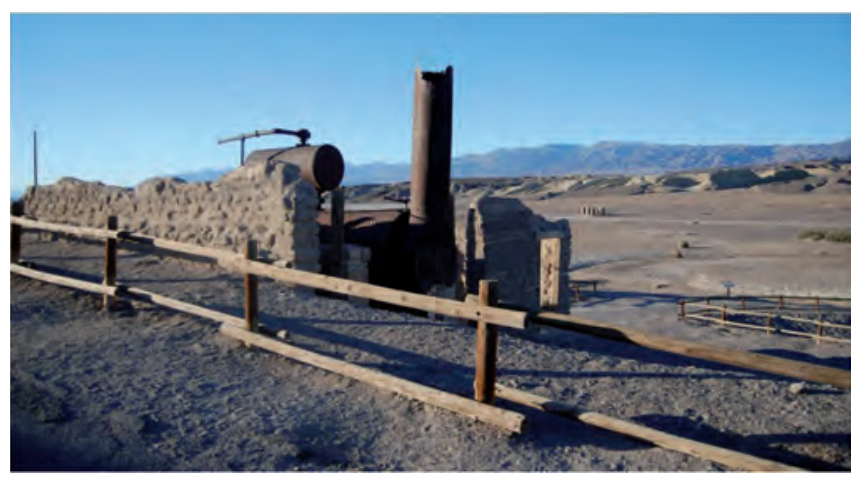

Fig. 8. Harmony Borax Works - one of first borax extraction sites in Death Valley, phot. E. Krzeszowska • Harmony Borax Works jedna z pierwszych „fabryk” boraksu w Dolinie Śmierci, fot. E. Krzeszowska

thick interbedded with fine-laminated mudstones (Fig. 9) (Tanner, 2002).

Boron minerals form under very specific geological conditions, mainly in deserts, where they precipitate in boron lakes related to post-volcanic springs. In Death Valley, the main boron minerals are:

borax $\mathrm{Na}_{2}\left[\mathrm{~B}_{4} \mathrm{O}_{5}(\mathrm{OH})_{4}\right] \times 8 \mathrm{H}_{2} \mathrm{O}$,

probertite $\mathrm{NaCa}\left[\mathrm{B}_{5} \mathrm{O}_{7}(\mathrm{OH})_{4} \times 3 \mathrm{H}_{2} \mathrm{O}\right.$,

ulexite $\mathrm{NaCa}\left[\mathrm{B}_{5} \mathrm{O}_{6}(\mathrm{OH})_{6}\right] \times 5 \mathrm{H}_{2} \mathrm{O}$

and colemanite $\mathrm{Ca}\left[\mathrm{B}_{3} \mathrm{O}_{4}(\mathrm{OH})_{3}\right] \times \mathrm{H}_{2} \mathrm{O}$. 


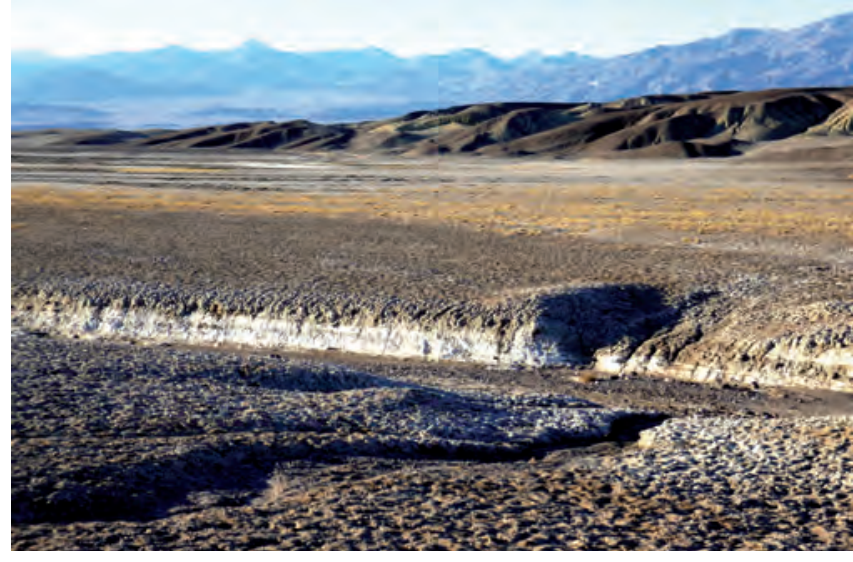

Fig. 9. Outcrops of bedded borate deposits - lower part of the Miocene-Pliocene Furnace Creek Formation, Death Valley, phot. E. Krzeszowska • Wychodnie warstw zawierających borany - dolna część mioceńsko-plioceńskiej formacji Furnace Creek, Dolina Śmierci, fot. E. Krzeszowska

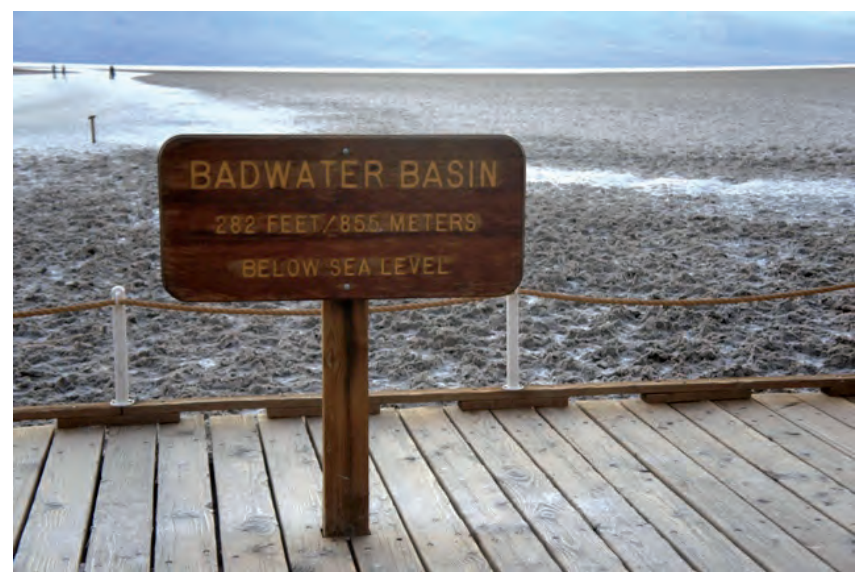

Fig. 10. Badwater Basin - the lowest elevation point in Death Valley, phot. E. Krzeszowska • Badwater Basin - najniżej położone miejsce w Dolinie Śmierci, fot. E. Krzeszowska

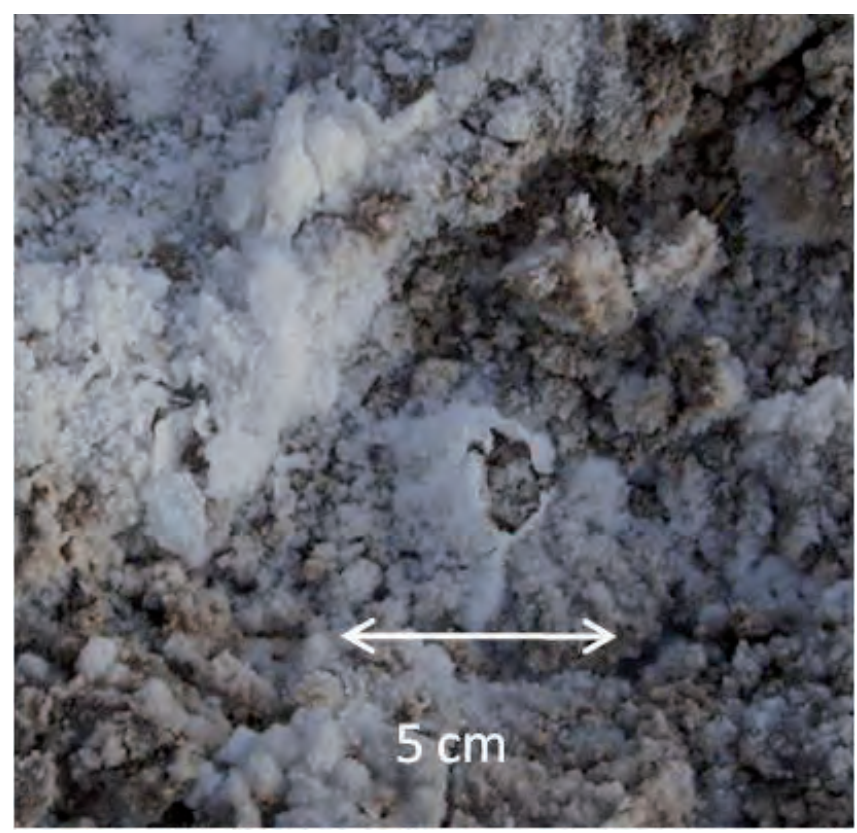

Fig. 11. Salt crystallization, Badwater Basin, phot. E. Krzeszowska - Krystalizacja soli, Badwater Basin, fot. E. Krzeszowska
From this list, colemanite was discovered in Death Valley and named after W.T. Coleman, an American businessman and owner of borate mines in which this mineral was described for the first time (Tanner, 2002). The Harmony Borax Works had been in operation in the years 1883-1888. Borates were mined and processes (refined) on site. The processing included multiple dissolution, settling of mineral impurities and reprecipitation of borates on metal rods in order to obtain highest possible concentration of borates in solutions. The product was then hauled with mule teams and wagons to railway station distant by some 200 kilometers from the mine. Unfortunately, high temperatures precluded the precipitation of borates in the summer. Both the harsh climatic conditions and transport problems resulted in the relatively early closure of the borate mine in Death Valley. In 1974 the Harmony Borax Works site was placed on the National Register of Historic Places.

Badwater Basin is the place of lowest elevation in Death Valley (85.6 meters below sea level). Simultaneously, this is the lowest elevation in the whole North America - the sea level is marked on the valley wall above the parking lot (Fig. 10). This also one of the hottest places on Earth. On July $10^{\text {th }}$, 1919 the weather station recorded the highest temperature in the United States: $+56.7^{\circ} \mathrm{C}$ (Miller, Wright, 2004). The Badwater Basin is located about 30 kilometers south of the Furnace Creek Visitor Center.

From geological point of view the Badwater Basin is a type of playa, i.e., a flat, endorheic terrain, which is an ephemeral lakebed covered with salt minnerals. Apart from the still active evaporation processes (Fig. 11), visitors can observe here the oldest rocks in Death Valley, exposed in the Black Mountains bordering the valley from the east. This is Proterozoic (1.7-1.8 Ga) Black Mountains Formation (Fig. 12) comprising mostly gneisses originated from regional metamorphism of crystalline basement and its Late Proterozoic-Cambrian sedimentary cover (Hall, 2007; Miller, Wright, 2004). Due to the complicated tectonics, the formation has been named "the Amargosa Chaos" because the rocks have been strongly folded and faulted during the Late Paleozoic and Mesozoic tectonic episodes. Additionally, the Amargosa Chaos includes a complex of clastics, mostly breccias composed of fragments of Precambrian, Cambrian and Neogene rocks (Hall, 2007; Miller, Wright, 2004).

In the northern part of the Badwater Basin there is the Devil's Golf Course - a huge fragment of valley floor covered with large (a dozen of centimeters across) lumps composed of soil and salt minerals (Fig. 13).

The Ubehebe Craters, of an area about 3 square kilometers, is located in the northern Death Valley. The main outlook and parking lot located at the western edge of the largest crater is accessible by bitumen road (about 60 kilometers distant from Highway 190). The bottom of the crater is accessible by a trail, but the return hike upslope can be rather difficult due to high temperatures. Less trained visitors are recommended to take a walk to the Little Hebe craters (about 1 kilometer) and/or a several-kilometers-long loop around the Ubehebe Crater edge. 


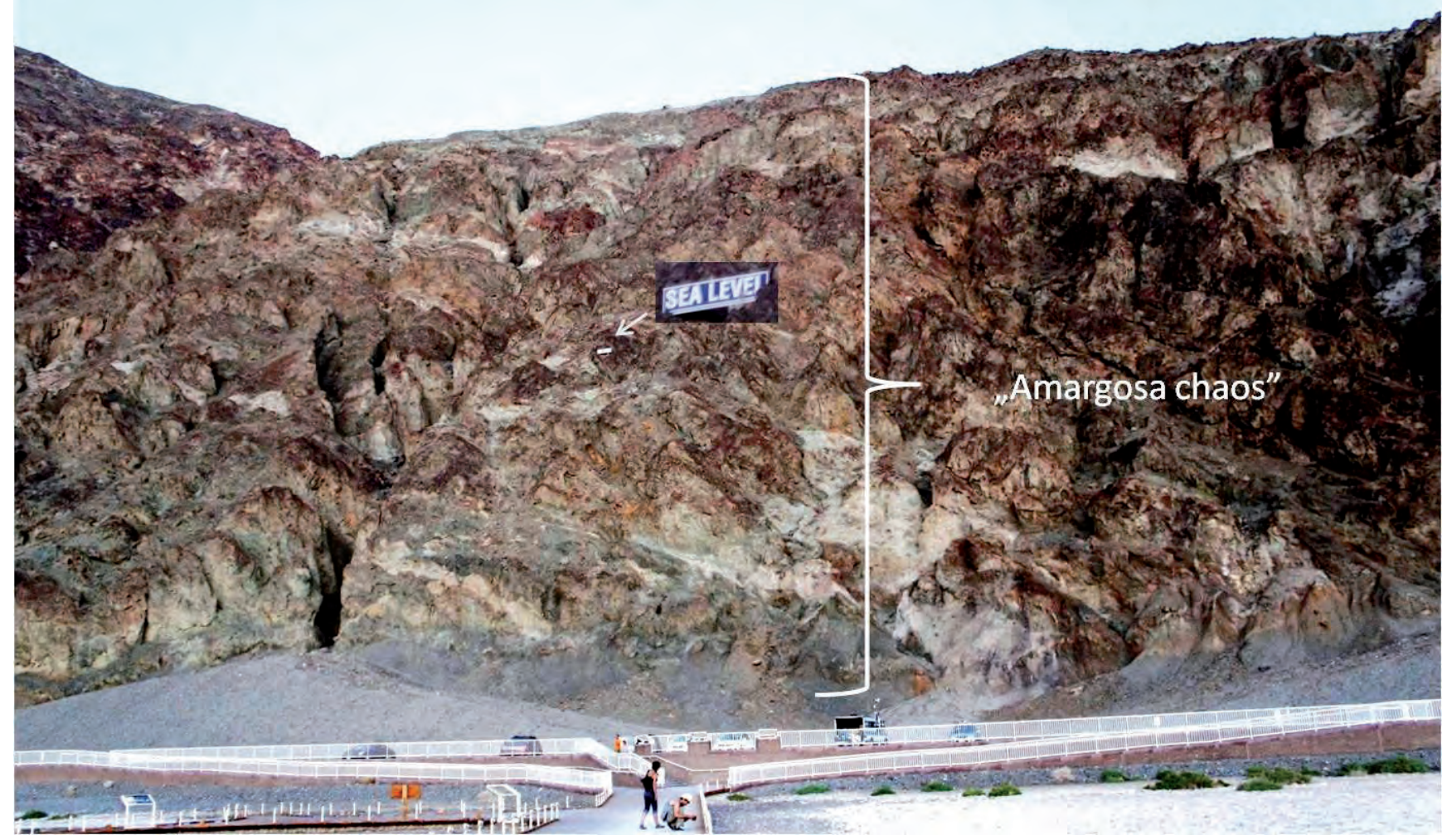

Fig. 12. The “Amargosa Chaos” Formation with marked sea level (Black Mountains), phot. E. Krzeszowska • Fomacja „Amargosa Chaos” z symbolicznie zaznaczonym poziomem morza (Black Mountains), fot. E. Krzeszowska

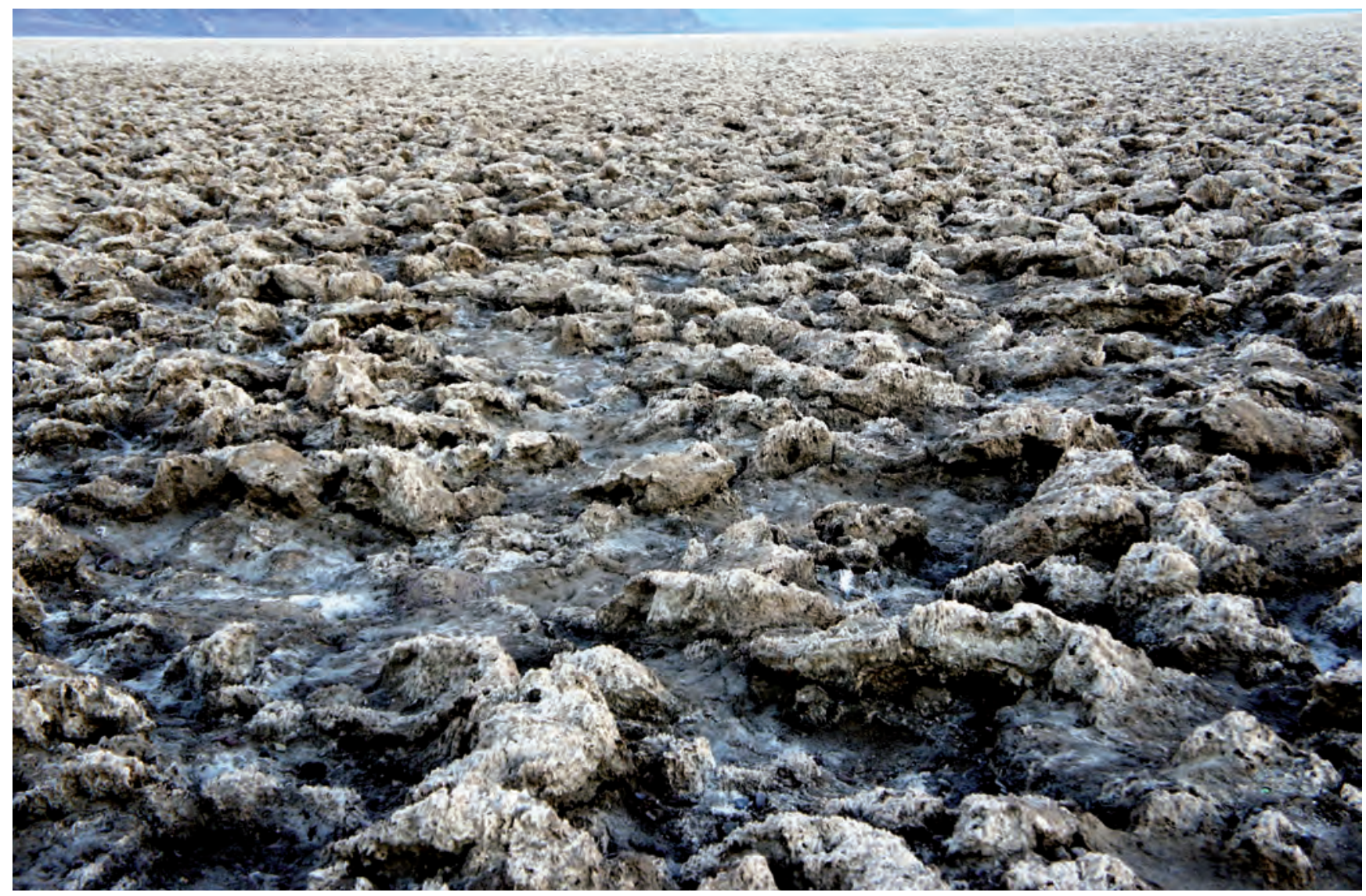

Fig. 13. Devil’s Golf Course, phot. E. Krzeszowska • Diabelskie pole golfowe, fot. E. Krzeszowska 


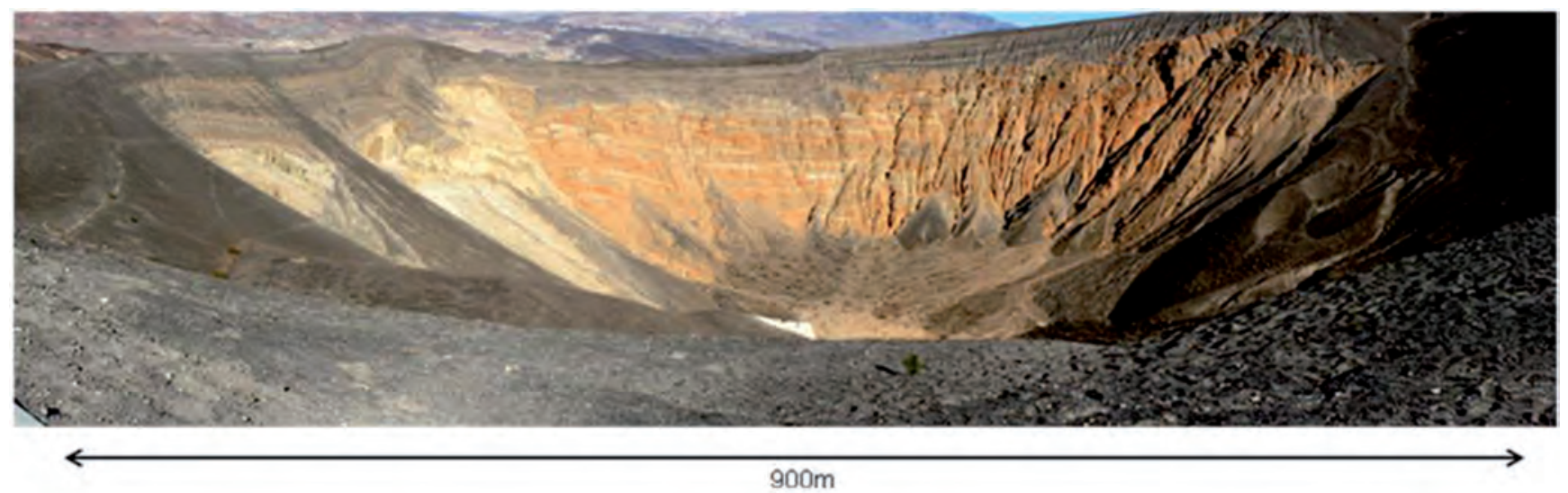

Fig. 14. Ubehebe Crater - panoramic view, phot. E. Krzeszowska • Panorama Ubehebe Crater, fot. E. Krzeszowska

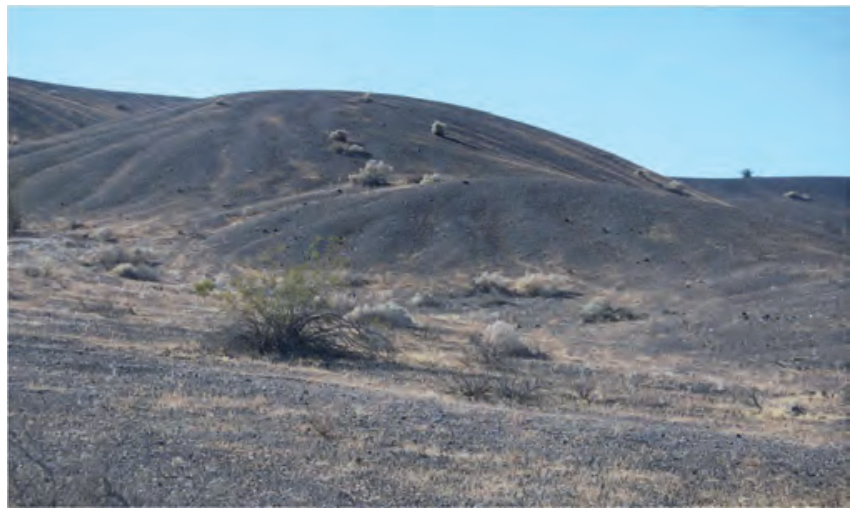

Fig. 15. Pyroclastic deposits in the Ubehebe Craters area, phot. E. Krzeszowska • Osady piroklastyczne w rejonie kraterów Ubehebe, fot. E. Krzeszowska

Fig. 16. Dip-slip fault (red line) seen in the northeastern slope of the Ubehebe Crater, phot. E. Krzeszowska • Uskok zrzutowy (czerwona linia) widoczny na północno-wschodnim zboczu krateru Ubehebe, fot. E. Krzeszowska
The Ubehebe Craters are a cluster of 12 maars originated from phreatic eruptions caused by extreme water vapour pressure built at the contact of groundwaters with magma or heated rocks (Wood, Kienle, 1990). In the crater walls the Miocene clastics can be observed (mostly fanglomerates and sandstones cemented with fresh-water carbonates) covered with the tuff rings (Crowe, Fisher, 1973). The top surface of clastics composing the crater walls is rough, with numerous, irregular erosional depressions left after the ephemeral lakes. Tuffs deposited along the crater rims are thin-bedded and laminated whereas thick-bedded sediments deposited in erosional depressions accumulated from debris flows (Crowe, Fisher, 1973) (Fig. 14). The total area covered by pyroclastics produced by volcanic eruptions is about 15 square kilometers (Fig. 15).

The youngest and the largest of craters is the Ubehebe, which is about 900 meters in diameter and 237 meters deep (Fig. 14). Its estimated age is about 6,000-7,000 years although some specialists claim a much younger age (Hall, 2007).

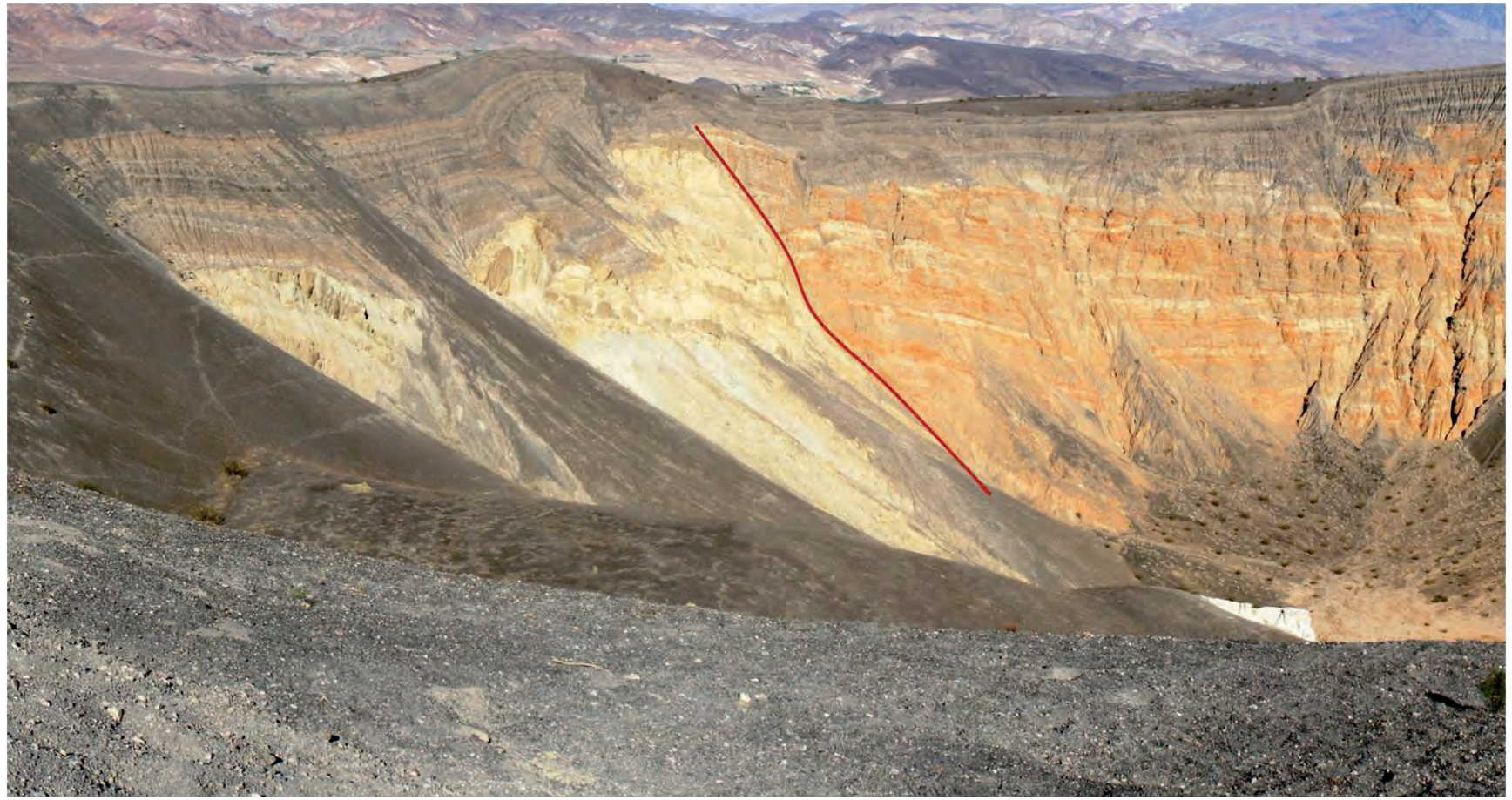


The Neogene volcanism in the Ubehebe area is related to the eruptions of trachybasalts along the fault zone cutting through the northern slopes of the Tin Mountain. The traces of Pleistocene tectonics related genetically to the Furnace Creek Foult Zone can be observed in the northeastern wall of the Ubehebe Crater, as a fault of throw about 120 meters (Fig. 16).

\section{Summary}

The Death Valley National Park is a handbook example of a dry, endorheic depression but it is also one of the most interesting and most diversified national parks in the USA. The selected geotourist attractions presented above are only a sample of what visitors can find in this area. The rocks exposed in the valley were formed during a time span from the
Precambrian to the Recent. Visitors are able to examine the traces of both the ancient and the recent geological processes including tectonics, volcanism and sedimentation. The advantage of Death Valley National Park is the scientific and educational potential. Moreover, the park is perfectly developed from a geotourism point of view. Visitor information is available at the park gates. Here, the tourist can obtain full information together with a park map and educational materials, from scientific papers to popular publications, photo albums and a variety of souvenirs. All geosites are perfectly prepared: from very instructive information boards to access roads, parking lots and restrooms. Due to the enormous geodiversity, Death Valley is worthy to be visited even for one day because a well-planned trip enables the tourist to see exceptional examples of geologic objects.

\section{Streszczenie}

\section{Wybrane atrakcje geoturystyczne Doliny Śmierci, USA}

\section{Ewa Krzeszowska}

Na terenie USA znajduje się 58 parków narodowych, obejmujących rozległe obszary pierwotnej przyrody. Jednym z najciekawszych i najbardziej różnorodnych pod względem geologicznym jest Park Narodowy Doliny Śmierci.

Dolina Śmierci (Death Valley) znajduje się w zachodniej części Stanów Zjednoczonych, w stanie Kalifornia i częściowo w stanie Nevada (Fig. 1).

Obszar ten stanowi najgorętszy i najbardziej suchy rejon w Ameryce Północnej, a jego najniżej położony punkt (86 m p.p.m.) to największe obniżenie na obszarze obu Ameryk.

Budowa geologiczna Doliny Śmierci jest charakterystyczna dla obszaru Prowincji Dolin i Grzbietów (Basin and Range Province) (Fig. 2). Jest to obniżenie (rów tektoniczny), którego formowanie rozpoczęło się w miocenie (Fig. 3), przecięte strefą uskokową, zwaną uskokiem Furnace Creek (Furnace Creek Fault Zone). Odsłaniają się tam skały wielu okresów geologicznych, od prekambryjskich skał metamorficznych po współcześnie tworzące się osady pustynne. Zachodnie i północno-wschodnie zbocza Doliny Śmierci zbudowane są głównie z silnie sfałdowanych i zuskokowanych morskich osadów paleozoiku, tworzących pasma górskie Panamint i Amargosa. W południowo-wschodniej części Doliny odsłania się formacja Amargosa Chaos, budująca Black Mountains - część pasma górskiego Amargosa (Fig. 4, 5). Dolina Śmierci wypełniona jest przede wszystkim osadami mioceńsko-plioceńskiej formacji Furnace Creek oraz osadami czwartorzędowymi (Fig. 5).

W artykule przedstawiono kilka najciekawszych obiektów geoturystycznych opisywanego rejonu.

Zabriskie Point to jeden z kilku wartych odwiedzenia punktów widokowych w Dolinie Śmierci. Skały otaczające Zabriskie Point to przede wszystkim osady wspomnianej wyżej formacji Furnace Creek (Fig. 6, 7). Formację tę budują głównie osady lądowe, zdeponowane w jeziorze uformowanym na tym obszarze ok. 9 milionów lat temu.
Harmony Borax Works to miejsce, gdzie zobaczyć można pozostałości po eksploatacji i przeróbce boraksu. Krótka trasa dydaktyczna z dobrze przygotowanymi tablicami informacyjnymi prowadzi wokół kilku historycznych obiektów (Fig. 8).

Złoża boranów w Dolinie Śmierci należą do dolnej części mioceńsko-plioceńskiej formacji Furnace Creek i występują w postaci serii skalnych o miąższości ok. $1 \mathrm{~m}$, przeławiconych drobno laminowanymi mułowcami (Fig. 9).

Badwater Basin to najniżej położone miejsce w Dolinie Śmierci (85,6 m p.p.m.) i, jednocześnie, najgłębsza depresja na kontynencie północnoamerykańskim (Fig. 10). Jest to również jedno z najcieplejszych miejsc na Ziemi. W 1919 roku stacja meteorologiczna zanotowała temperaturę $+56,7^{\circ} \mathrm{C}$. Badwater to obszar typu „playa”, czyli płaski, bezodpływowy teren stanowiący dno wyschniętego, okresowego jeziora. Pokryty jest on płatami solnymi, które okresowo przybierają regularne, sześciokątne formy o boku długości ok. $2 \mathrm{~m}$. Na terenie Badwater Basin, obok wciąż zachodzących procesów ewaporacji (Fig. 11), obserwować można najstarsze skały odsłaniające się w Dolinie Śmierci. Są to głównie proterozoiczne gnejsy o wieku 1,7-1,8 mld lat. Zbudowane z tych skał wzgórza Black Mountains (część pasma górskiego Amargosa Range) otaczają Badwater Basin od strony wschodniej (Fig. 12). W północnej części Badwater Basin znajduje się Devil's Golf Course (Diabelskie Pole Golfowe) - olbrzymi fragment dna doliny pokryty kilkunastocentymetrowymi bryłami ziemi zmieszanej z minerałami solnymi (Fig. 13).

Rejon kraterów Ubehebe Craters, o powierzchni około $3 \mathrm{~km}^{2}$, znajduje się w północnej części Doliny Śmierci i obejmuje 12 wulkanicznych kraterów eksplozywnych typu maar. Najmłodszym i największym z nich jest Ubehebe, krater o średnicy około 900 m i głębokości 237 m (Fig. 14). W okolicy kraterów pyły i popioły wulkaniczne pochodzące z erupcji wulkanicznych zdeponowane są na obszarze $15 \mathrm{~km}^{2}$ (Fig. 15). W północno-wschodnim zboczu krateru widoczne są Ślady plejstoceńskiej tektoniki uskokowej, związanej ze strefą uskokową Furnace Creek, w postaci uskoku o zrzucie około 120 m (Fig. 16).

Wszystkie obiekty geoturystyczne Doliny Śmierci mają bardzo wysoką wartość naukową, dydaktyczną i estetyczną oraz doskonałe zagospodarowanie turystyczne. 


\section{References (Literatura)}

Baucke W., Cemen I., 2007. Strike-Slip displacement along the Furnace Creek Fault Zone, southern Basins and Ranges, Death Valley. American Geophysical Union, Fall Meeting, abstract, T31C-0594.

Brogan G.E., Kellogg K.S., Slemmons D.B., Terhune C.L., 1991. Late Quaternary Faulting Along the Death Valley - Furnace Creek Fault System, California and Nevada. U.S. Geological Survey Bulletin, Denver.

Crowe B.M., Fisher R.V., 1973. Sedimentary Structures in Base-Surge Deposits with Special Reference to Cross-Bedding, Ubehebe Craters, Death Valley, California. GSA Bulletin, 842: 663-682.

Hall C.A., 2007. Introduction to the geology of southern California and its native plants. University of California Press, Berkeley, Los Angeles.

Kistler R., 2005. Borate deposits of The Furnace Creek Formation, Death Valley. Salt Lake City Annual Meeting, 209: 3.

Konott J.R., Sarna-Wojcicki A.M., Machette M-N., Klinge R.E., 2005. Upper Neogene stratigraphy and tectonics of Death Valley - a review. Earth-Science Review, 73: 245-270.
Levin H.L., 2005. The Earth Through Time, 8th Edition. John Wiley \& Sons, Inc., USA.

Miller M.B., Wright L.A., 2004. Geology of Death Valley National Park, 2nd ed. Kendall-Hunt Publishing, Dubuque, Iowa.

Mizerski W., 2004. Geologia regionalna kontynentów, Wydawnictwo Naukowe PWN.

Stanley S.M., 2002. Historia Ziemi. Wydawnictwo Naukowe PWN.

Tanner L.H., 2002. Borate formation in a perennial lacustrine setting: Miocene-Pliocene Lacustrine and Marginal Lacustrine Sequences of the Furnace Creek Formation. Sedimentary Geology, 148: 259-273.

Wood Ch.A., Kienle J., 1990. Volcanoes of North America. Cambridge University Press.

Web sites:

http://geomaps.wr.usgs.gov/parks/

http://mappery.com/map-of/Death-Valley-National-Park-Map-3 